\title{
Information and Communication Technology in the Rehabilitation of Hearing-Impaired Children
}

\author{
Mihaela Konjevod \\ Faculty of Humanities and Social Sciences, University of Zagreb, Croatia \\ mihaela.konjevod94@gmail.com \\ Vesna Mildner \\ Faculty of Humanities and Social Sciences, University of Zagreb, Croatia \\ vmildner@ffzg.hr \\ Tomislava Lauc \\ Faculty of Humanities and Social Sciences, University of Zagreb, Croatia \\ tlauc@ffzg.hr
}

\begin{abstract}
Summary
This paper deals with the use of information and communication technology in the development of phonological awareness in children with hearing impairment. The research was conducted at Polyclinic for the Rehabilitation of Listening and Speech (SUVAG). The Glaskalica app on a tablet device has been used to compare the phonological awareness test results that are obtained by using the paper-pencil method and through information and communication technology. There were 10 participants aged 6 to 8 years (four girls and six boys). The results show that ICT is interesting and motivating to children and has the potential to improve phonological awareness skills.
\end{abstract}

Key words: children with hearing impairment, information and communication technology, rehabilitation, education, phonological awareness

\section{Introduction}

Today, computer literacy and information literacy are as important as general literacy. That is why children should become familiar with information and communication technology (ICT) from early preschool age. ICT, especially in the rehabilitation and education of hearing-impaired children, plays a significant role in providing visual feedback, keeping attention and motivation. The technology effectively addresses the difficulties faced by the hearing-impaired child during speech development. Nikolić Margan and Bunčić (2016) have demonstrated that use of technology contributes to the prolongation of concentration during rehabilitation, for 15-20 minutes.

The first computer system for speech rehabilitation was developed by Nickerson and Stevens (1973). To date, many systems, programs, and applications for hearing therapist have been developed. The SpeechViewer II program, together with the therapist, has enabled the prelingually deaf boy to establish a proper voice height (Öster, 1995). With the AURIS program, three out of five hearingimpaired children between two and six years old who had not previously verbally communicated learn at least one new term. Children did not show boredom during the teaching process. With the program, the children successfully and correctly pronounce the terms and differentiate the meaning of different sentences with the same term (Sarmaşik et al., 2009).

The ARTUR program increased interest in children with hearing impairment to practice pronunciation. The main advantage of the program is providing feedback in the form of clear instructions on how to improve articulation (Engwall et al., 2006). Nasiri et al. (2017) have developed the game by which children can learn words that they are expected to know by the age of seven. The game consists of an avatar controlled by the child's voice commands. During the game, an object appears in the scene, and avatar collides with that object and object's sound is played and repeated by the child. After the child completes this teaching phase, s/he enters the test phase and system show us her/his improvement by giving validation recognition percentage" (Nasiri et al., 2017: 6). 
Research on the impact of information and communication technology on education and rehabilitation of children with a hearing impairment has shown positive results. More attention is being given to applications that can be used on a tablet and mobile devices because it is proved that these devices are more appropriate and easier for pre-school and early school-age children (Geist, 2014). Besides, it is proved that there is a positive correlation between the use of ICT and academic achievement of pupils with hearing impairment (Egaga, Aderibigbe, 2015) and a positive correlation between playing on tablet and self-esteem (Bahatheg, 2014).

\section{Phonological awareness}

The development of reading skills is one of the most important tasks of early education. This is also one of the most challenging tasks faced by children with severe and profound hearing impairment (Harris, Beech, 1998). "Phonological awareness refers to the recognition, creation and handling of smaller parts of the word, such as recognizing the words that are being rhymed, counting the syllables, separating the beginning of the word from the end, and separating the letters in the words" (Pavliša, Lenček, 2011: 2). Rakhshanfadaee and Salehi (2016) researched first-class pupils who had moderately and profound hearing impairment. They proved that the pupils had acquired phonological awareness skills and could make phonological decisions. Children with profound hearing impairment had greater difficulties than those with severe impairment, but both groups had weaker results compared to hearing children and those with moderate hearing impairment. It has been shown that the degree of hearing damage also plays a major role in the development of phonological awareness. Cognitive abilities, short-term verbal memory, and language comprehension are also important. This means that a child needs to understand a particular speech part, keep it long enough in memory, and then realize it verbally (Sindik, Pavić, 2009). Also, the beginning of the rehabilitation process and use of a cochlear implant or other hearing aids also plays a major role. It should be mentioned that these and many other factors influence the results obtained by examining phonological awareness in this study.

\section{Problem statement and research goal}

The influence of ICT on the development of phonological awareness in children with impaired hearing is insufficiently explored. Besides, in Croatia, there is hardly any research on ICT in the rehabilitation and education of children with hearing impairment. Also, it is necessary to develop the appropriate information and communication technologies, programs and applications so that the health and pedagogical system can follow the changes in the modern era. The purpose of this study was to raise awareness of the importance of ICT use in working with hearing-impaired children. In Croatia, this is a group for which the tools and applications have recently been developed. The goal of this study was to investigate the effectiveness and importance of ICT in working with hearingimpaired children. The research objectives were:

- To find out whether the results of phonological awareness are better if the information and communication technology is used.

- To find out whether therapists and hearing-impaired children have a positive attitude towards information and communication technology.

\section{Methodology}

The research was conducted in two meetings, individually with children and their therapists. In the first meeting, the children recognized missing phonemes in words on paper (the first, the last, and all phonemes in the word). The words were taken from the Glaskalica app. In the next meeting, the children recognized missing phonemes in words in the Glaskalica app. Participants filled out the questionnaires regarding phonological awareness and motivation.

\section{Participants}

Ten participants aged six to eight who have impaired hearing were involved in this study. They all go to the kindergarten or first grade of primary school in Polyclinic SUVAG. There were six boys and four girls, which is a total of two participants at the age of eight, six at the age of seven and two at the age of six. The participants where A, B, C, D, E, F, G, H, I and J. There were also four therapists: 1, 2, 3 and 4 . This is shown in Table 1. 
Table 1. Therapists, work experience in rehabilitation and child participants

\begin{tabular}{|l|l|l|}
\hline Therapists & Experience in rehabilitation & Child participants \\
\hline 1 & 21 years & G \\
\hline 2 & 9 years & I, J \\
\hline 3 & 25 years & C, D \\
\hline 4 & 25 years & A, B, E, F, H \\
\hline
\end{tabular}

\section{Materials}

In this research, ICT-AAC Glaskalica app was used. Glaskalica has been developed within the ICTAAC project "Competence network based on information and communication technologies for innovative services aimed for people with complex communication needs". The established competence network enables collaboration, knowledge transfer and technology for people with complex communication needs. The ICT-AAC Glaskalica app helps in improving phonological awareness. Phonological awareness is important for reading comprehension. The application involves recognizing the first, the last, and all phonemes in words. In addition, the application distinguishes tasks according to their complexity. There are over 200 words in the application that have been selected by the experts. Each word is presented to the user by an image representing the term corresponding to the given the word. The words can be pronounced so that users, besides the visual template, can also have a sound template. That is very useful and important for hearing-impaired children. On the home screen, the user can choose one of the three games. The games differ according to the position and the number of phonemes that must be chosen. Before starting the game, the user selects the complexity of the words that will be offered during the game. Easier or difficult tasks can be selected. After selecting the desired complexity, the image appears on the screen. The user has to guess the first, the last or all phonemes, depending on the selected game. Children with normal speech development first recognize the words that rhyme. Then they can separate the word into syllables. Five-year-olds can recognize the first and the last phoneme in the word. The ICT-AAC Glaskalica app is the first application in the Croatian language that encourages the development of phonological awareness. The app is intended for use on portable devices such as tablet and mobile devices. The previously developed technology for stimulating these aspects is based on computer programs, which is maybe not the best for pre-school children. ${ }^{1}$

\section{Questionnaires}

The research methodology employed in this study was based on self-made questionnaires. There were five questionnaires. The questionnaire for testing phonological awareness was made using the words from the ICT-AAC Glaskalica app. There were ten different words in which the first phoneme needed to be guessed, ten words in which the last phoneme needed to be guessed and ten words where all phonemes in the word needed to be guessed. This questionnaire was used for testing the phonological awareness skills by the paper-pencil method. The questionnaire for monitoring the child's response while using the app was created to record correct and incorrect answers of children. If they did not know the right answer from the first attempt, the answer was considered incorrect. Because three phonemes are given to them and if they don't know the right answer from the first attempt, they are finding the answer throughout the method trial and error, and that is not representing their true phonological awareness. The questionnaire for examining how much the children enjoyed using the Glaskalica app consisted of eight questions. A 5-point Likert scale was used in this questionnaire. The questions were: "Did you like this game?" "Did you get bored while playing this game?", "How hard was it to play this game?", "Would you like to play this game again?", "Would you like to play this game together with your friends or family?", "Was this game too long?", "Was this game too short?", "Have you already played a similar game, if you did what is the name of the game?" The last two questionnaires were made for therapists. In the first one, they present their own opinions and impressions on how the child behaves in a rehabilitation class where information technology was used. The questions were: "How much did a child like this game?", "Was the child bored when playing this game", "How hard was it for the child to play this game?" and the space for comments if

\footnotetext{
${ }^{1} \mathrm{http}: / /$ www.ict-aac.hr
} 
there is any. Consideration was also given to the therapists' opinion on how much a child was satisfied because they are experts who are working with the child constantly and they can recognize the child's satisfaction or dissatisfaction. In the second questionnaire, they provided answers to the questions: "How much did you like the app?", "How useful would this application be for rehabilitation?" To address these questions, a 5-point Likert scale was used in the questionnaires for therapists.

\section{Testing phonological awareness}

The research was conducted in two meetings, individually with each participant for 15 to 25 minutes, depending on the abilities of the individual participant. It started at the end of September 2018 and was completed in December 2018. The research was carried out in the room for individual rehabilitation in kindergarten and room for individual rehabilitation in elementary school of the Polyclinic for the Rehabilitation of Listening and Speech, SUVAG (with the consent of the parent and the participants). During the first meeting, each participant independently solved the tasks of recognizing the first, the last, and all phonemes in words on paper. There were three groups of tasks, consisting of ten tasks each (ten for the first, ten for the last and ten for all phonemes in the word). Under each word, three phonemes were offered, of which the participant should decide for the one (s)he heard. Firstly, the word was read to the participant, if necessary, a few times, and then (s)he independently selected a single phoneme using the pencil. Each next word was read, and then the participant chose the phoneme (s)he heard from the offered phonemes and so on to the end. During the second meeting, participants solved the tasks of recognizing missing phonemes using the Glaskalica app. It was possible to distinguish tasks in the application according to their complexity. Thus, more manageable tasks were used. The questions from the questionnaires regarding motivation were asked after the end of the testing session.

\section{Results and discussion}

Measurement of phonological awareness was carried out in two different ways. The aim was to compare the results obtained by using the paper-pencil method and the results obtained with the ICT. The average test score in recognition of the first phoneme by using the paper-pencil method was $94 \%$, with results ranging from $80 \%$ to $100 \%$. In recognition of the first phoneme using the app, the average score was $86 \%$ with results ranging from $60 \%$ to $100 \%$. One participant scored $60 \%$, and three scored $70 \%$. Also, they achieved the lowest results in the overall survey. Children recognized the first phoneme in the word better if the words were on paper. In this case, the use of ICT has not given better results (Figure 1).

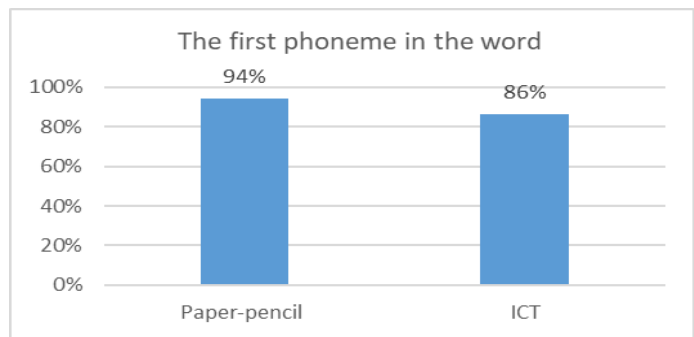

Figure 2. The average test score of recognizing the first phoneme

In recognition of the last phoneme using a paper-pencil method, the average test score was $80 \%$, with results ranging from $40 \%$ to $100 \%$. In recognition of the first phoneme using the app, the average test score was $89 \%$, with results ranging from $50 \%$ to $100 \%$. When using ICT as learning support, children recognized the last phoneme slightly better compared to paper as a medium (Figure 2). 
M. Konjevod, V. Mildner, T. Lauc. Information and Communication Technology...

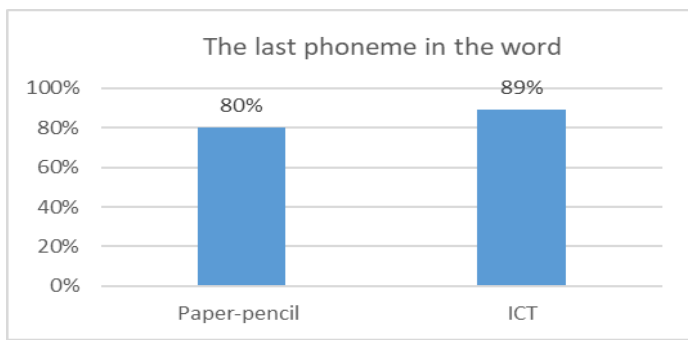

Figure 2. The average test score of recognizing the last phoneme

The average test score of the recognition of all phonemes in the word with the paper-pencil method was $52 \%$, with results ranging from $10 \%$ to $100 \%$. In recognition of the first phoneme through the information and communication device, the average test score was $56 \%$, with results ranging from $10 \%$ to $100 \%$. In this case, children were slightly better at recognizing the order of all phonemes in the word using the app (Figure 3).

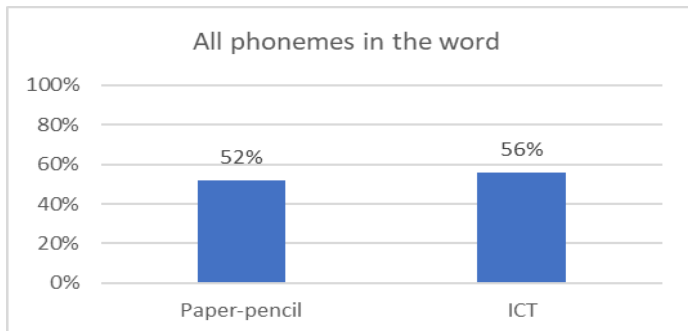

Figure 3. The average test score of recognizing all phonemes

Although children recognized the first phoneme in the word slightly better if the word was on paper, out of the total number of participants, $50 \%$ had the same maximum score or even better score in recognizing the first phoneme using the app. Out of the total number of participants, $90 \%$ had the same maximum score or better score in recognizing the last phoneme using the app. Out of the total number of participants, $50 \%$ had the same maximum score or better score in recognition of the order of all phonemes in the word using the app. After the end of the testing session, the questions from a pre-prepared questionnaire were asked to identify participants' interest in the application. Response from the therapist is presented in parallel with the child's answers, as it is shown in Figure 4. The question was: "How much did you like this game?" The child and the therapist were able to choose a number from 1 to 5 ( 1 meaning non-liking at all, 5 meaning liking very much). There was a slight difference regarding participants $\mathrm{D}, \mathrm{F}$, and $\mathrm{G}$ and therapists.

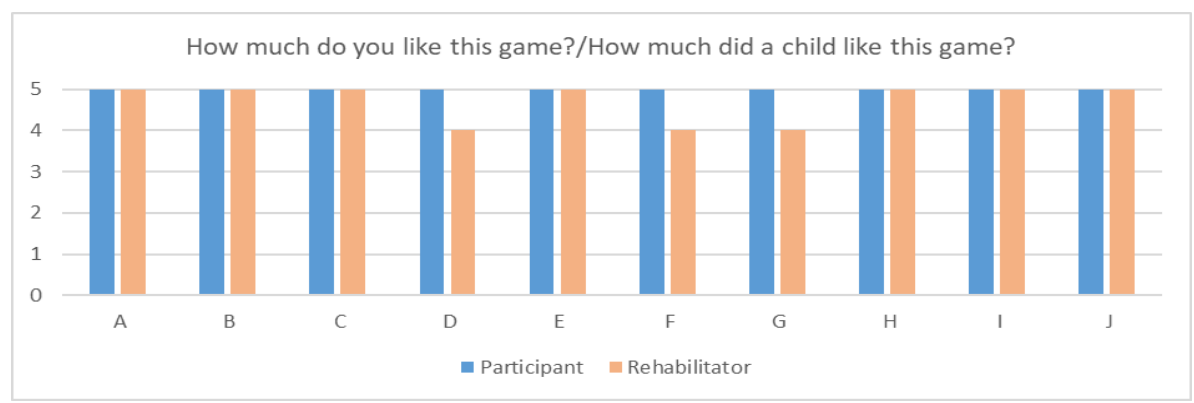

Figure 4. Comparison of children's and therapists' answers.

As shown in Figure 5, the question was "Did you get bored while playing this game?" The child participants were able to choose a number from 1 to 5 , where number 1 represents the absence of boredom, and number 5 represents a great presence of boredom. Nine out of 10 participants (90\%) responded with number 1 , such indicating that it was not boring at all while playing this game. Only one participant responded with number 3. Because of the difficulty of establishing meaningful communication with participant $\mathrm{F}$, the therapist's response indicated to us that the child liked the application. 


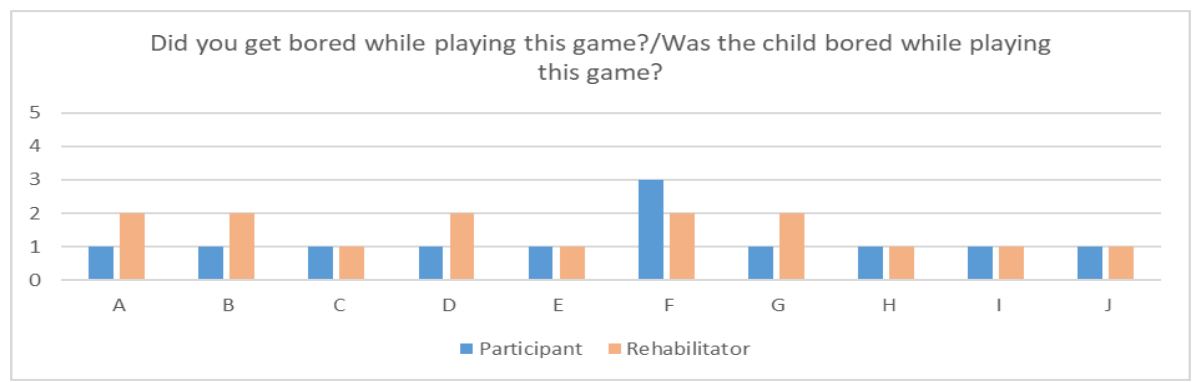

Figure 5. Comparison of children's and therapists' answers

As shown in Figure 6, the question was "How difficult was it to play this game?" The participants were able to choose a number from 1 to 5 . Number 1 indicated that the game was not at all difficult, and the number 5 indicated that it was very difficult. Seven out of the 10 participants $(70 \%)$ have chosen number 1 , such indicating that it was not difficult at all during the game. Three out of the 10 participants have chosen number 3, such indicating that this game was neither difficult nor easy. For two participants, this game was difficult or very difficult. The answers of the child participants approximately match the answers of the therapists. A large difference between participants and therapist responses is found regarding participant B since the therapist saw how much time a child needed to choose the right answer.

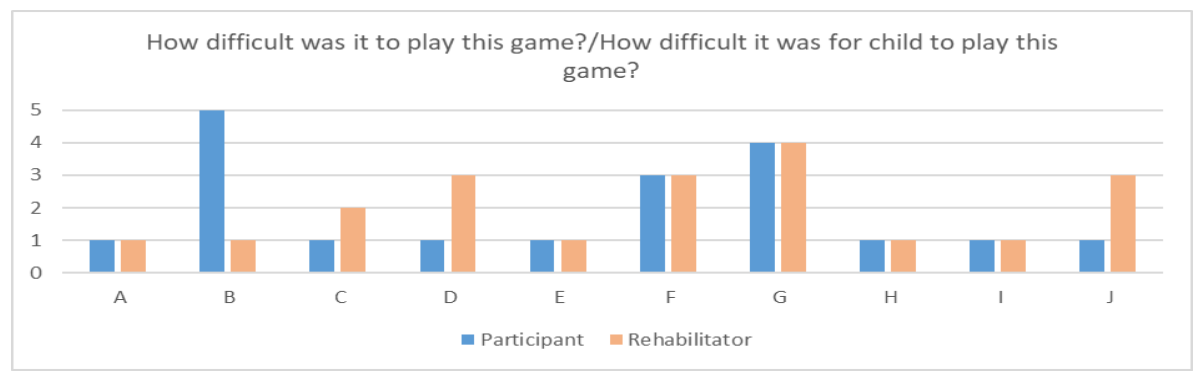

Figure 6. Comparison of children's and therapist's answers

For children participants, there were 5 questions with yes/no responses. All participants answered that they would love to play this game again. Nine out of 10 participants answered that they would like to play this game together with friends or family, and that game was not too long or too short. Five out of 10 participants answered that they have already played a similar game, although, they did not know the name of the game. The answers from the questionnaire for therapists showed that they all like the app and find it useful or very useful. Also, all of them think that some form of ICT should be used in the rehabilitation of hearing impairment.

\section{Limitations of the research}

The words on paper were the same for all participants. But on the tablet, the words were automatically generated by the application. Therefore, for results that were better or worse by using ICT, we can't say with certainty that these are solely due to the use of ICT. To use such game-designed apps, in the rehabilitation of children with hearing impairment, it should be possible to choose the words that are going to be used at a rehabilitation class. Also, the research was carried out on a small number of subjects and a suitable sample. It should be mentioned that the group of children was heterogeneous with respect to their level of speech development.

\section{Conclusion}

The study shows that children with hearing impairment have a positive attitude toward information and communication technology and that they are happy to use it. This is also the opinion of their therapists. All therapists have realized the importance and the need to use the Glaskalica application as well as other educational applications. The results indicate that ICT has the potential to improve phonological awareness skills. What should be the main goal of each rehabilitation method is to 
enable the child with hearing impairment to achieve speech communication and to develop language and their abilities. If information and communication technology can help in that process, it should be included in the pedagogical and health care system, thus increasing the chances of most children with impaired hearing to develop their skills for communication.

\section{References}

Bahatheg, R. O. (2014). Deaf children and iPad technology: Improving the self-concept of deaf and hard of hearing children. // Canadian International Journal of Social Science and Education 1, 107-120

Egaga, P., Aderibigbe, I., Akinwumi, S. (2015). Efficacy of information and Communication technology in enhancing learning outcomes of students with hearing impairment in Ibadan. // Journal of Education and Practice. 6, 30, 202-205

Engwall, O., Bälter, O., Öster, A. M., Kjellström, H. (2006)- Designing the user interface of the computer-based speech training system ARTUR based on early user tests. // Behaviour and Information Technology 25, 4, 353-365

Geist, E. (2014). Toddlers through preschool: Using tablet computers with toddlers and young preschool. // YC Young children $69,1,58-63$

Harris, M., Beech, R. J. (1998). Implicit phonological awareness and early reading development in prelingually deaf children. // Journal of Deaf Studies and Deaf Education. 3, 3, 206-216

Nasiri, N., Shirmohammadi, S., Rashed, A. (2017). A serious game for children with speech disorders and hearing problems. // IEE $5^{\text {th }}$ International Conference on Serious Games and Applications for Health, 1-7

Nickerson, R., Stevens, N., K. (1973). Teaching speech to the deaf: can a computer help? // Audio and Electroacoustics, IEEE Transactions. 21, 445-455

Nikolić Margan, A., Bunčić, A. (2016). Razvoj aplikacije za pomoć u rehabilitaciji djece sa govorno-jezičnim poremećajima. // Sveučilište u Zagrebu, 1-63

Öster, A. M. (1995). Teaching speech skills to deaf children by computer-based speech training. //Proceedings of 18th International Congress on Education of the Deaf, Tel Aviv, Israel

Pavliša Ivšac, J., Lenček, M. (2011). Fonološke vještine i fonološko pamćenje: neke razlike između djece urednog jezičnog razvoja, djece s perinatalnim oštećenjem mozka i djece s posebnim jezičnim teškoćama kao temeljni prediktor čitanja. // Hrvatska revija za rehabilitacijska istraživanja 47, 1, 1-16

Rakhshanfadaee, A., Salehi, M. (2016). Phonological awareness in children with hearing loss. // The Hearing Journal 69, 9 , $32-35$

Sarmasik, G., Serbetcioglu, B., Kut, A. (2009). Computer aided education and training tool for hearing impaired children: AURIS. // ICL Proceedings, 427-433.

Sindik, J., Pavić, M. (2009). Povezanost općih kompetencija i fonološke svjesnosti kod predškolske djece. // Život i škola 22, 2, 62-77 